\title{
Prevalence of syphilis diagnosed in female inmates of city Ponta Porã
}

\author{
Rafael Henrique Oliveira Lopes ${ }^{1 *}$, Isabella Jacó Carrijo ${ }^{1}$, Maisa Estopa Correa ${ }^{1}$, Marco Antonio Moreira Puga ${ }^{2}$, \\ Ana Rita Coimbra Motta Castro ${ }^{3}$, Sandra Maria do Valle Leone Oliveira ${ }^{3}$, Julio Henrique Rosa Croda ${ }^{4}$, \\ Grazielli Rocha Rezende ${ }^{2}$, Larissa Melo Bandeira ${ }^{2}$, Everton Ferreira Lemos ${ }^{2}$, Simone Simionatto
}

From 5th Congress of the Brazilian Biotechnology Society (SBBIOTEC)

Florianópolis, Brazil. 10-14 November 2013

\section{Background}

Syphilis is a growing public health problem in several countries. The infection is systemic, usually involving mucocutaneous ulcers and rashes in the early phases, and a range of serious complications including cardiovascular and neurological disease in later phases [1,2]. Global control of syphilis is hampered by slow and insensitive diagnostic methods, particularly for risk population like prison inmates $[3,4]$. This study aimed to analyze the prevalence and socio-demographic, behavioral and institutional factors associated with Treponema pallidum infection in prison women in Ponta Porã city, Mato Grosso do Sul.

\section{Methods}

The study was conducted from January to September 2013 and the sample size was calculated based on the prevalence of syphilis in Brazil. The sample was randomly selected and included 74 female inmates in Ponta Porã. To determine the prevalence of Treponema pallidum infection, blood samples were collected for serological tests using a treponemal test named enzyme-linked immunosorbent assay (ELISA) and a non-treponemal test e venereal disease research laboratory (VDRL). Each test was performed in accordance with manufacturer's recommendations. Socio-demographic and clinical information, as well as variables related to transmission were collected in a standard questionnaire. Research Electronic Data Capture (REDCap) is being carried out to store data. The study was approved by the Research Ethics Committee of the Universidade Federal da Grande Dourados, Brazil.

\section{Results}

During the study, 11 cases of Treponema pallidum infection were identified, which represents a prevalence of $14.8 \%$. The serology analyses showed that the prevalence was higher than other studies, where the prevalence ranged from $0.5 \%$ and $7.5 \%$ [5]. The risk factors are still being evaluated by REDCap. Different studies have shown an increased vulnerability of the incarcerated population to syphilis, associated to other factors like high-risk sexual behavior. The quality of incarcerated women's life could be improved by routine infection diagnosis, the implantation of a screening program for the health problems and systematic education.

\section{Acknowledgements}

This work was supported by the PROEXT 2013 (MEC/SESu) and Foundation Support the Development of Education, Science and Technology of the State of Mato Grosso do Sul (FUNDECT, 04/2013).

\section{Authors' details}

${ }^{1}$ Federal University of Grande Dourados, Dourados, Mato Grosso do Sul,Brazil. ${ }^{2}$ Infectious Diseases, Federal University of Mato Grosso do Sul, Dourados, Brazil. ${ }^{3}$ Federal University of Mato Grosso do Sul, Dourados, Brazil. ${ }^{4}$ Faculty of Health Sciences, Federal University of Grande Dourados, Dourados, Brazil.

Published: 1 October 2014

\section{References}

1. Duarte G: Syphilis and pregnancy...the story continues! Rev Bras Ginecol Obstet 2012, 34(2):49-51.

2. Adjei AA, Armah HB, Gbagbo F, Ampofo WK, Boamah I, Adu-Gyamfi C, Asare I, Hesse IFA, Mensah G: Correlates of HIV, HBV, HCV and syphilis infections among prison inmates and officers in Ghana: A national multicenter study. BMC Infect Dis 2008, 8:33.

3. Azbel L, Wickersham JA, Grishaev Y, Dvoryak S, Altice FL: Burden of infectious diseases, substance use disorders, and mental illness among Ukrainian prisoners transitioning to the community. PLoS One 2013, 8(3): e59643. 
4. Chen XS, Wang QQ, Yin YP, Liang GJ, Jiang N, Yang LG, Liu Q, Zhou YJ, Huan XP, Wei WH, Wang B: Prevalence of syphilis infection in different tiers of female sex workers in China: implications for surveillance and interventions. BMC Infect Dis 2012, 12:84.

5. Garriga C, Gómez-Pintado P, Díez M, Acín E, Díaz A: Characteristics of cases of infectious syphilis diagnosed in prisons, 2007-2008. Rev Esp Sanid Penit 2011, 13(2):52-57.

doi:10.1186/1753-6561-8-S4-P81

Cite this article as: Oliveira Lopes et al.: Prevalence of syphilis diagnosed in female inmates of city Ponta Porã. BMC Proceedings 2014 8(Suppl 4):P81.

Submit your next manuscript to BioMed Central and take full advantage of:

- Convenient online submission

- Thorough peer review

- No space constraints or color figure charges

- Immediate publication on acceptance

- Inclusion in PubMed, CAS, Scopus and Google Scholar

- Research which is freely available for redistribution

Submit your manuscript at www.biomedcentral.com/submit
C Biomed Central 